\title{
MEALS ON WHEELS OF TAMPA CONFRONTS COVID-19 ${ }^{1}$
}

\author{
The people that needs us the most are the same people experts are saying are most at-risk!
}

Steve King, Executive Director at Meals on Wheels of Tampa (MOWT), had this realization in February 2020 when discussions about COVID-19 started to flood the airwaves. In a way, it was a blessing in disguise, because it put him into action mode much earlier than other business leaders in the community. Steve had been leading the organization for fourteen years. Things were going remarkably well up to this point. Community support and donations were strong, and the program had steadily grown for the last decade, a testament to Steve's leadership. However, this challenge was completely different from any they had ever seen. COVID-19 had the potential to attack the very heart of the organization's mission.

MOWT delivered close to 870 hot meals per weekday to the elderly and homebound in the Tampa community. The meals were made in their own kitchen and were carefully crafted to nourish this segment of the population. Beneficiaries of the program truly depended on it, not only because of their inability to procure their own meals, but also because for some, this was the only nutritious meal they ate every day. How did they do it? Steve would promptly praise his staff, the wonderful volunteers that delivered the meals (the "wheels" part) and the tremendous support of community sponsors and donors. This complex logistical operation ran like a well-oiled machine after years of constant refining under Steve's supervision.

When the COVID-19 pandemic started lurking in early 2020, it was very clear that it would be a large disruptor to the MOWT operation. First, they needed measures to protect not only the staff and volunteers, but the very people they served, as they were the most at-risk. Secondly, an increase in meals requests was clearly expected, as experts' guidelines strongly recommended that elders stay home.

It was all hands on deck at this point. Several brainstorming sessions ensued. The prospect of suspending the operation came up but was quickly shut down. "Right now is when they need us the most," several people remarked. The next alternative became clear: continue to operate while reducing physical contact as much as possible. What did that mean? Reduce the number of beneficiaries? Reduce the number of weekly meals delivered? Deliver all weekly meals in one day? Outsource some parts of the operation?

It seemed like every option had ramifications to consider. The worst part, Steve thought, were the pandemic related uncertainties that could not be anticipated at this point.

\footnotetext{
${ }^{1}$ Copyright (C) 2020, Federico Giovannetti. This case was prepared for the purpose of class discussion, and not to illustrate the effective or ineffective handling of an administrative situation. Names and some information have been disguised. This case is published under a Creative Commons BY-NC license. Permission is granted to copy and distribute this case for non-commercial purposes, in both printed and electronic formats.
} 


\section{Food Insecurity in America}

One of the definitions of "hunger" in the Merriam-Webster dictionary is "a weakened condition brought about by prolonged lack of food". In 2006, the United States Department of Agriculture (USDA) started to make a clear distinction between the definitions (and measuring) of hunger and food insecurity in America. Food insecurity is defined as a household-level economic and social condition of limited or uncertain access to adequate food (US Department of Agriculture, 2019). Hunger was, in fact, a possible consequence of food insecurity.

\section{Influential Factors}

Hunger was quite commonly linked to poverty. However, food insecurity was a much more complex problem than hunger and it was influenced by many factors besides poverty. In fact, not everyone living below the Federal poverty level suffered food insecurity and some people living above the Federal poverty level did suffer food insecurity. Among the factors that influenced access to nutritious food were (Lloyd, 2017):

- Affordability: determined by household income and size, includes poverty levels

- Availability: or difficulty of getting to the food sources. It could be based on distance, transportation options, business hours, etc.

- Health: mobility, exposure to environment, mental health

- Education: food choices

- Life balance: working long hours or multiple jobs

- Environment: any changes in the environment that affect the supply chain, such as natural disasters

Depending on what factors were in play for a household or individual, food insecurity could be permanent or temporary. The elderly population was, perhaps, the most susceptible to being affected by multiple factors from the list above. In addition, the effects of food insecurity on the health of American seniors were devastating. Exhibit 1 illustrates such effects and their social and lifestyle consequences, which connect directly with the MOWT mission.

\section{Measuring and Levels}

According to USDA, there were four levels of food security (US Department of Agriculture, 2019). Notice that although the most common term used when referring to this issue was "food insecurity", these USDA levels were defined using the inverse terminology: "food security". All this meant was that high food insecurity was equivalent to low food security. The four levels in question were:

- High food security: no reported indications of food-access problems or limitations.

- Marginal food security: one or two reported indications - typically of anxiety over food sufficiency or shortage of food in the house; little or no indication of changes in diets or food intake.

- Low food security (previously known as food insecurity without hunger): reports of reduced quality, variety, or desirability of diet; little or no indication of reduced food intake.

- Very low food security (previously known as food insecurity with hunger): Reports of multiple indications of disrupted eating patterns and reduced food intake. 


\section{Latest Statistics}

Between 2011 and 2018, anywhere between one in six to one in nine U.S. households suffered food insecurity (low food security as defined by the USDA), and up to one in 20 suffered from very high food insecurity (very low food security) or in more common terminology, hunger. Exhibit 2 provides detailed statistics on food insecurity in the United States, including a break down by employment, education, and disability status.

In terms of the statistics related to the elderly population, according to Lloyd (2017), it was estimated that in 2016 approximately ten million older adults suffered from food insecurity in the United States. This was equivalent to $16 \%$ (one in six) of older adults.

\section{Charitable Organizations}

In the United States, the term charitable organization usually refers to an organization with a tax-exempt status under section 501(c)(3) of the tax code. According to the Internal Revenue Service (IRS), in order to enjoy tax exempt status, a charitable organization must pursue goals that are beneficial to the public interest (US Internal Revenue Service, 2020). The IRS provides a list of examples of such organizations' main activities:

- Relief of the poor, the distressed, or the underprivileged,

- Advancement of religion,

- Advancement of education or science,

- Erection or maintenance of public buildings, monuments, or works,

- Lessening the burdens of government,

- Lessening of neighborhood tensions,

- Elimination of prejudice and discrimination,

- Defense of human and civil rights secured by law, and

- Combating community deterioration and juvenile delinquency.

Organizations had to go through an application process to obtain tax exempt status under section 501(c)(3) as well as comply with strict filing requirements and disclosures to maintain it. MOWT had been a 501(c)(3) charitable organization since 1975.

\section{Funding}

Charitable organizations typically procured their funding via donations, both from individuals and corporations. Those who donate could receive a tax deduction up to the full amount of the donation as long as the charitable organization was officially approved as a 501(c)(3) organization by the IRS.

The fundraising activities in a charitable organization were very involved. First, its mission had to appeal to the audience from which it was soliciting funds. Second, it had to demonstrate that it was carrying out its mission effectively. Third, it had to demonstrate a fiduciary responsibility in carrying out that mission or, in other words, that it was utilizing the funds it had been entrusted in a responsible way.

To show transparency and responsibility in carrying out their mission, most charitable organizations published an annual report detailing all their activities, accomplishments and financial details. In addition, 
maintaining 501(c)(3) status required detailed yearly filings with the IRS. See Annual Reports \& Financials (2020) for samples of all annual reports, audited financial statements and IRS forms published by MOWT.

\section{Landscape}

In November 2018, the Urban Institute's National Center for Charitable Statistics published a brief (McKeever, 2018) containing key statistics about the nonprofit sector in the U.S. Some of the highlights were:

- Approximately 1.56 million nonprofits were registered with the IRS in $2015.59 .3 \%$ of them belonged to the 501(c)(3) category.

- The nonprofit sector contributed an estimated \$985.4 billion to the US economy in 2015 (5.4\% of GDP).

- In 2017, total private giving from individuals, foundations, and businesses totaled $\$ 410.02$ billion.

- An estimated 25.1 percent of US adults volunteered in 2017, contributing an estimated 8.8 billion hours.

Exhibit 3 lists the Forbes top ten charities in America of 2019.

\section{Charity Ratings}

As indicated above, the charitable sector was significant, and so was Americans' willingness to give and volunteer. Charity Navigator, founded in 2001 and a 501(c)(3) organization itself, evaluated charities based on financial health, accountability and performance (Charity Navigator, 2020). By 2019, they had become the most utilized evaluator of charities, having had more than 11 million visits to their website in 2018 alone. According to their website (Charity Navigator, 2020), "Our ratings show givers how efficiently we believe a charity will use their support today, how well it has sustained its programs and services over time and their level of commitment to good governance, best practices and openness with information". The ratings consisted of a numerical score that was translated by range to a star-based rating according to the following table:

$\begin{array}{cccccc}\text { Overall Rating: } & 4 \text { Stars } & 3 \text { Stars } & 2 \text { Stars } & 1 \text { Star } & 0 \text { Stars } \\ \text { Overall Score: } & \geq 90 & 80-90 & 70-80 & 55-70 & <55\end{array}$

MOWT had a 4 Stars rating by Charity Navigator in 2020 (Charity Navigator, 2020a).

\section{Meals on Wheels of Tampa}

Meals on Wheels of Tampa (MOWT) was a privately funded charitable organization based in Tampa, Florida. As stated in their mission statement, they were "committed to fulfilling the mission of nourishing, enriching and strengthening the lives of our homebound and senior community." They fulfilled this mission by preparing, packaging, and delivering hot meals daily from Monday through Friday. As of February 2020, approximately 870 daily meals were being delivered in the Tampa community.

MOWT was founded in 1975 by Tampa resident Gloria Fuentes. She saw the need for a community organized effort to help the homebound, as she herself struggled to help two of her own relatives. The original group of volunteers delivered 14 daily meals that were cooked in the kitchen of a local church. 
More kitchens from neighboring churches and organizations kept the program going (and growing) until 1993, when MOWT purchased its own building equipped with a commercial kitchen as well as office space. Exhibit 4 presents a complete timeline of MOWT's milestones through its history since 1975.

\section{Meals on Wheels nationwide}

In 2020, there were approximately 5,000 Meals on Wheels organizations in the United States. They each served a specific geographical area, typically a local community. They all had the same mission: to serve the elderly and the homebound. They came in all sizes; some delivered a couple of dozen meals a day, some delivered thousands of meals a day. MOWT was relatively large, somewhere around $25^{\text {th }}$ in size ranking (the largest being $1^{\text {st }}$ ). In addition to ranging widely in size, they operated in drastically different ways, based on their funding model and the intricacies of the community to which they belonged.

Most of these organizations were members of Meals on Wheels America, including MOWT. Meals on Wheels America supported local organizations in several ways, such as providing training (recruiting volunteers, fundraising, logistics, menu selection, etc.), legislative support, and access to government funding. They also hosted a yearly national conference where local organizations met to share ideas and experiences. Unlike about $88 \%$ of the Meals and Wheels organization nationwide, MOWT did not call on Meals on Wheels America for access to government funding. However, Steve still considered them to be a very helpful and supportive resource.

\section{Organizational Structure}

The organizational structure of MOWT consisted of a board of directors, an executive director, a leadership team, other paid staff and an extensive number of volunteers. Exhibit 5 provides a detailed list of the members of the organization as of May 2020, as well as their respective roles/titles.

\section{Executive Director}

Steve King was the Executive Director of Meals on Wheels of Tampa. He reported to the board of directors and led a team of 26 employees. Steve was the selected candidate in the search for a new Executive Director conducted by the MOWT board of directors in 2006 . He had been on the job for almost 14 consecutive years.

Steve graduated from the University of South Florida in Tampa in 1980 with a bachelor's degree in Religious Studies. He then went on to pursue a Master of Divinity degree from the Vanderbilt Divinity School at Vanderbilt University, graduating in 1983. Later that year, Steve was ordained as United Methodist minister and started serving as pastor of Van Dyke Methodist church in North Tampa. After approximately 12 years at Van Dyke, Steve became the pastor at Palm Harbor United Methodist church in Pinellas county, where he served for another 12 years or so. As mentioned above, his next position was at MOWT where he still served as of mid-2020. During his tenure at MOWT, he returned to the pastorate and served on the weekends at a small congregational church in Ana Maria Island. In summary, Steve's long career reflected one remarkable trend: a heart and passion to serve people.

As Executive Director of MOWT, Steve divided his time between three main activities: business development (funding), staff management, and volunteer-related activities.

\section{Business Development}

MOWT did not depend on any government funding or grants. This had been a strategic decision from the beginning, providing MOWT with total flexibility in their operations. All of their funding was private and 
developed organically. Steve dedicated about 50\% of his time to development activities. As a 501(c)(3) charitable organization, MOWT pursued corporate sponsorships as well as community donations. Thanks to the consistent work of Steve and the board, MOWT was fortunate to count on an impressive list of donors in the Tampa area. Exhibit 6 presents a table depicting the number of donors per donation amount for the fiscal year ending June 2019.

During the prior few years, Steve spearheaded important strategic initiatives in pursuit of new funding. Seeing how well the made-in-house meals were received and the level of productivity the kitchen had achieved, he set out to be a provider to other non-profit organizations. The best example of these new activities was a program with Tampa General Hospital (TGH). MOWT delivered meals to patients who have been released from the hospital and might be experiencing food insecurity (permanent or temporary due to health fragility). These meals were funded by TGH and were an important part of the patients' recovery protocol that normally followed release from the hospital.

Based on the development activities described above, MOWT enjoyed a very steady financial picture. In fact, they were in the process of moving to a new building across the street that would house a new kitchen with a capacity of 3-4 times the current one. The larger kitchen allowed MOWT to continue to grow both the traditional home delivery program for the elderly and homebound, as well as the more recent non-profit organizations program.

\section{Staff management}

Steve spent about $30 \%$ of his time meeting with his leadership team and staff to address daily operational issues, whether routine or unforeseen. The daily operation of the MOWT organization included areas such as:

- Kitchen operation

- Vendor management

- Volunteer coordination

- Finances and accounting

- Partners relationships

- Delivery logistics

- Human Resources

\section{Volunteers}

Volunteers were a very important part of MOWT. They delivered the meals every day using their own vehicles and resources. In some cases, they were the only human contact beneficiaries had throughout the day. Steve spent another $20 \%$ of his time in activities related to volunteers, such as recruiting, orientation, newsletters, and especially organizing appreciation events such as the annual volunteers luncheon and small details like a colorful birthday card (see Exhibit 7).

\section{Additional Programs}

MOWT had spun off a few additional programs to further help the beneficiaries. These programs historically originated from special campaigns or interest from specific sponsors in the community. 


\section{Water on Wheels (WOW)}

This program added an $8 \mathrm{oz}$ water bottle to the daily delivery. It also included educational material highlighting the importance of hydration for the elderly. As of early 2020, this program was funded by a single sponsor.

\section{Produce on Wheels (POW)}

Through this program, beneficiaries received a bag of produce once a month. The program augmented the nourishing goals by adding fresh fruits and vegetables to the beneficiaries' diet. The feedback from the beneficiaries had been overwhelmingly positive.

\section{Hurricane Preparedness Pack}

This single-sponsor program provided shelf stable meals and bottled water to beneficiaries at the beginning of Florida's hurricane season. The packs were meant to be a backup in case the regular service was interrupted due to a storm.

\section{Celebrations}

An important part of the MOWT program was to nourish the soul as well as the body. Volunteers were trained to greet and do a conversational daily wellness check that was much needed and craved by the elderly and homebound. This was augmented by celebrating special occasions, such as:

- Birthday card and cake (delivered on recipient's birthday with daily meal delivery)

- Thanksgiving Visit (Thanksgiving morning - card and sweet treat)

- Holiday Gift Bag (third Saturday in December)

\section{The Meals, AND the Wheels}

The MOWT operation functioned as a well-oiled machine thanks to continuous refinements made over the years. Distributing almost 900 hot meals every day was not a small feat. MOWT did it effectively and efficiently. In fact, their top-notch logistics allowed the organization to expand the program in several different ways. Steve was quick to praise his staff and volunteers for these accomplishments, although his 14 years at the helm of such a successful operation showed the significance of his leadership. The two main components providing such efficiency and flexibility were: (1) the meals (food preparation and packaging) and (2) the wheels (distribution of the meals).

\section{The Meals}

Steve described the success of the meals operation with just two words: "Chef Tony". Chef Tony Pineda moved to Tampa in 2005 after a successful career in New York City at a large catering company. As his official title (Executive Chef / Senior Food Services Officer) indicated, he oversaw the entire kitchen operation. He hired, trained and managed the kitchen staff, which as of early 2020 consisted of about 15 employees. His passion for the MOWT mission and his daily enthusiasm was well known to all involved in the MOWT operation, and to many outside of it, as he had even been featured in the local news (WTSP Staff, 2016).

The MOWT kitchen was subject to the same strict regulations, required licenses, and recurring inspections as any restaurant kitchen in the area. 
Chef Tony's menu planning included a thorough nutritional analysis to make sure that each meal contained the necessary nourishment for MOWT's target beneficiaries. Each meal included the following:

- 1 serving of a lean protein (beef, chicken, pork, or fish)

- 1-2 servings of starch (potato, pasta, or rice)

- 1-2 servings of vegetables

- 1 dessert (pudding or fruit)

Additionally, each meal contained at least 600 calories and less than $800 \mathrm{mg}$ of sodium.

\section{Who could get a meal?}

The only criteria for eligibility was being part of the target population; in other words, being elderly or homebound. These criteria mapped directly onto the MOWT mission and Steve proudly claimed that they did not deny service to anyone who needed it. In addition, MOWT targeted food insecurity at a broader spectrum that is not just based on poverty. Even if they could afford it, most recipients lived alone and were unable to prepare a meal by themselves. Those that could afford their meal did pay for it. They were priced on a sliding scale starting at $\$ 5.50$ per meal, down to $\$ 0.00$ per meal depending on the individual's monthly income. According to Steve, about $30 \%$ of the beneficiaries did not pay anything for their meals, another $40 \%$ paid between $\$ 0.50$ and $\$ 3.50$ and the remaining $30 \%$ paid the full price of the meals.

\section{Flexibility}

In light of Chef Tony's experience and passion for the mission of MOWT, Steve was never concerned about the performance of this part of the operation. On the contrary, Steve viewed it as a tremendous advantage in terms of flexibility. He figured that he could maximize the kitchen's utilization in order to sell the additional meals produced. The additional revenue would help the long-term sustainability of the organization and the main mission of the program. Steve had executed this strategy optimally, placing the extra meals with institutions that also served the elderly and homebound, such as hospitals, nursing homes and health insurance companies. This meant that a larger proportion of the same meals would be completely paid for, and still going to people in need; a win-win for everyone involved. The success of this strategy in part motivated the pursuit of the new building with a larger kitchen.

\section{The Wheels}

In the words of Executive Director Steve King: "there are no two ways around it. We could not fulfill our mission if it weren't for our great volunteers." This was easy to confirm looking at the numbers: 870 meals divided into approximately 785 households grouped into 82 routes that each needed to be covered in approximately 1.5 hours. Covering all of those routes simultaneously around lunch time every day would require 82 employees or independent contractors. Not only would it be difficult to pay for this operation, but it would also be virtually impossible to find that many individuals with that type of availability.

\section{Volunteers}

MOWT had never lacked willing volunteers to give their time and resources to deliver the meals. All volunteers were screened through a background check and attended mandatory orientation prior to delivering their first meal. Orientation emphasized to volunteers that their role went beyond delivering a package. The objective was to nourish both the body and the soul of the elderly and homebound by 
delivering a hot meal and a friendly greeting or conversation. The latter also served as a daily wellness check that was always needed for individuals with fragile health conditions.

\section{Adopt-A-Route}

Volunteers could also sign up as a group through the Adopt-A-Route initiative. Adopt-A-Route allowed companies, churches, and other civic organizations to commit to deliver meals for a specific route, typically in the vicinity of their location. Organizations that signed up were asked to designate a leader that would recruit and coordinate volunteers as well as liaise with MOWT regarding route scheduling and any other matters. The Adopt-A-Route program had been very successful as illustrated by the number of participating organizations listed in Exhibit 8.

\section{Technology}

MOWT made the logistics involved in handling the daily deliveries very easy for the volunteers, mostly through extensive use of technology. There were two main technology components: the route mapping software, and the web based "volunteer hub" where volunteers could sign up for days and routes online.

The route mapping software was used by many Meals on Wheels organizations across America. It hosted the database of recipients with their addresses as well as the addresses of the existing distribution centers. Based on this data, it created optimized routes through which to deliver meals. Each route was composed of anywhere between 8 and 12 stops. The software printed out a suggested delivery order for each route, including step-by-step directions that started at the nearest distribution center for each route. As of May 2020, there were 17 distribution centers and 82 routes. The centers located in more densely populated areas had more routes starting from them. Volunteers would go to their assigned distribution center and pick up a cooler with the meals and the printout for the assigned route. All they had to do was follow the directions to cover all the stops. The printout also contained the names of the recipients and phone numbers to call in case they did not come to the door.

The volunteer hub was a web-based sign-up system showing available routes for upcoming delivery dates. Volunteers used their login credentials to pick the dates and routes they wanted to cover. An accompanying page provided details on what section of town was covered by each route and the address of the associated distribution center. Volunteers that did not have online access could call the office to reserve a route.

\section{The Covid-19 Pandemic Hits}

On January $11^{\text {th }}, 2020$, China reported the first worldwide death attributed to the previously unknown virus. The first death in the U.S. was recorded on February $29^{\text {th }}$ and on March $11^{\text {th }}$, the World Health Organization (WHO) declared it a global pandemic after previously announcing that it was a new strain of the coronavirus (named Covid-19) (Muccari, Chow, \& Murphy, 2020).

Steve and his staff went into full "Covid-19 mode" around the second week of March. By that time, there were several widely known facts based on advisories published by the WHO and the U.S. Centers for Disease Control and Prevention (CDC). The following list includes some of these facts, namely those that impacted the MOWT operation.

1. The virus was highly contagious, transmitting mostly by droplets from sneezing, coughing or other secretions from the mouth. These droplets could directly contaminate other people or land on surfaces, where the virus could live for hours or even days. 
2. The most common way for healthy people to get infected was by getting the virus on their hands and then touching their mouth, nose or eyes. This was how the virus entered the body.

3. The degree to which individuals got sick because of the virus varied quite significantly, from being completely asymptomatic to being admitted to the hospital with severe symptoms. The mortality rate was around $1-5 \%$ of those infected.

4. The advisories clearly indicated that the most vulnerable individuals to succumb to the virus were the elderly and those with existing morbidities, especially immunodeficiencies.

5. Based on the information above, WHO and CDC advisories urged people to:

a. Wash hands with soap or use hand sanitizer several times per day.

b. Use disposable gloves when touching surfaces that others had touched before.

c. Clean surfaces exposed to lots of people often and thoroughly.

d. Significantly reduce physical contact with others outside the home. This will be better remembered by terms such as "social distance", "stay at home" and "shelter in place".

According to Steve, the direct effect of these advisories on the MOWT operation were as follows:

1. Most MOWT beneficiaries belonged to the most at-risk group, the elderly. It would be devastating if MOWT brought the virus to them in any way, shape, or form.

2. The kitchen operation (the meals) would be impacted. There would undoubtedly be new protocols to follow in terms of sanitizing surfaces, handling of food and containers, and screening staff, among others.

3. The delivery operation (the wheels) would be impacted

a. By definition, volunteers would not be following "stay at home" advisories when delivering meals. How could MOWT protect them from getting infected? Were they in some way contributing to the spread of the pandemic by potentially being unwilling carriers of the virus?

b. There was bound to be a significant drop in the number of volunteers delivering meals, as they would likely decide to follow the "stay at home" advice to avoid getting the virus. Additionally, as most companies moved their staff to working remotely, the concept of Adopt-A-Route volunteer groups was for the most part invalidated.

4. Requests for MOWT's services were most likely to increase. As the elderly were strongly advised to shelter in place, food insecurity in that group automatically went up based on environmental factors.

Fortunately, Steve did not believe that the financial standing of MOWT would be affected by the pandemic. He knew from experience that the community always rallied in times of need with overwhelming support. In addition, their emergency funds account - or cash on hand - was in good standing (Annual Reports \& Financials, 2020).

\section{The Decision}

As Steve and his staff discussed what to do regarding the effects of the pandemic on their daily operations, could they consider options at opposite ends of the spectrum? At one end, the decision could be to do nothing and continue to prepare and deliver the meals as usual. At the opposite end, the decision could be to suspend the operations altogether. However, neither option seemed to align with their mission and commitment to the elderly and homebound. Those two options were quickly dismissed, and brainstorming began around several middle of the road options that would concentrate on continuing operations while minimizing physical contact as much as possible. 
These were the options discussed:

- Reduce the number of weekly meals delivered, maybe 3 times a week instead of 5 times a week. This would reduce the exposure to the virus for volunteers and recipients but will leave the recipients suffering from food insecurity to fend for themselves for a couple of days. Perhaps the hurricane preparedness kits could be used for those days.

- Deliver all weekly meals in one day.

This would reduce the exposure to the virus even further, but the meals would have to be either frozen or non-perishable. The quality of the meals delivered would not be the same but at least the recipients would have all weekly meals covered. Some recipients, those with the most food insecurity, where already getting frozen meals for the weekends before the pandemic.

- Implement a meal pick up option.

Perhaps some percentage of the recipients could count on a relative or friend to pick up their meals instead of getting them delivered. Although this option would protect the volunteers from exposure, it would bring a handful of issues to the table if pursued.

- Purchase the meals instead of preparing them.

Even though the exposure factor could be controlled to a larger extent in the kitchen than in the delivery operation, the kitchen was also impacted. Everything related to sanitizing surfaces, providing protective equipment to kitchen staff, and sanitizing the daily supplies brought in, represented additional complications for the kitchen operation. Purchasing the meals would help dealing with these new challenges. However, as seen throughout this case, preparing the meals in house was a major advantage to MOWT, and this option would eliminate it. Was it worth it, even if for a limited time?

- Outsource the delivery of the meals.

This option would eliminate exposure for the volunteers but would not guarantee that the recipients would be protected as well. Volunteers could be trained on a new protocol to deliver the meals, including staying at least six feet away from recipients, wear gloves, sanitize hands after each deliver, etc. Outsourcing would leave the implementation of similar protocols up to the outsourced company. Another problem would be the unknown cost associated with outsourcing the delivery of the meals and the uncertainty of how long it would need to be implemented.

Every option or combination thereof had different ramifications to be considered. The team had to make a decision sooner rather than later as the positive cases of Covid-19 increased by the day all around the country. In addition, there were uncertainties that could not be anticipated that could render a good decision today the worst decision in a month. Under this tremendous pressure, Steve had the most dreadful thought yet: "what if someone crucial to the team got infected with the virus?" 


\section{References}

Annual Reports \& Financials. (2020, February 29). Retrieved June 16, 2020, from

https:/MOWTampa.org/about-MOWT/annual-reports-financials/

Charity Navigator (2020). Your Guide To Intelligent Giving. Retrieved June 15, 2020, from

https://www.charitynavigator.org/

Charity Navigator (2020a). Meals on Wheels of Tampa (Charity Profile). Retrieved June 16, 2020, from https://www.charitynavigator.org/index.cfm?bay=search.summary\&orgid=11052

Lloyd, Jean L. (2017, February). Hunger in Older Adults: Challenges and Opportunities for the Aging Services Network. (C) Meals on Wheels America. Retrieved from: https://www.mealsonwheelsamerica.org/docs/default-source/research/hungerinolderadults-fullreportfeb2017.pdf

McKeever, B. (2018, November). The Nonprofit Sector in Brief 2018: Public Charities, Giving, and Volunteering. Retrieved June 14, 2020, from https://nccs.urban.org/publication/nonprofit-sector-brief2018

Muccari, R., Chow, D., \& Murphy, J. (2020, June 04). Coronavirus timeline: Tracking the critical moments of COVID-19. Retrieved June 10, 2020, from https://www.nbcnews.com/health/healthnews/coronavirus-timeline-tracking-critical-moments-covid-19-n1154341

US Department of Agriculture, (2019). Definitions of Food Security. Available online at: https://www.ers.usda.gov/topics/food-nutrition-assistance/food-security-in-the-us/definitions-of-foodsecurity.aspx

US Internal Revenue Service. (2020). Publication 557: Tax-Exempt Status for Your Organization.

WTSP Staff. (2016, November 22). Former New York City chef dedicated to Meals on Wheels. Retrieved May 16, 2020, from https:/www.wtsp.com/article/news/local/former-new-york-city-chef-dedicated-tomeals-on-wheels/355010748

\section{Acknowledgements}

I would like to thank the Meals on Wheels of Tampa organization for the incredible work they do in the community and for making it easy for me to be an appreciative volunteer. I would like to thank Steve King for his generous time and thourough accounts as I interviewed him several times during the discovery phase leading up to this work. Thank you to my daughter Isabel for reviewing my writing and my classmates in the USF DBA program for their helpful feedback. 


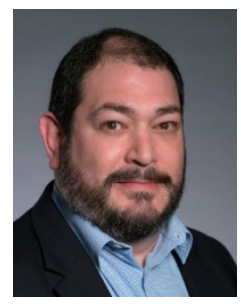

\section{Biography}

Federico Giovannetti is a doctoral student at the University of South Florida MUMA College of Business. He is also a Director of Data Security at Trellance, Inc. in Tampa, Florida. His research interests consist of finding ways to improve the cybersecurity culture in organizations.

Federico is an enthusiastic volunteer delivering meals for Meals on Wheels of Tampa. 


\section{Exhibit 1: Effects of food insecurity on America's senior population}

\section{FOOD INSECURITY HARMS THE HEALTH OF MANY OLDER ADULTS AND THEIR ABILITY TO REMAIN IN THE COMMUNITY}

Food insecurity among older adults is more likely to have adverse health consequences than in other age groups. For example, food insecure older adults are $50 \%$ more likely to have diabetes; three times more likely to suffer from depression; $60 \%$ more likely to have congestive heart failure or a heart attack; $30 \%$ more likely to have at least one ADL impairment; and twice as likely to report gum disease and asthma. ${ }^{8}$
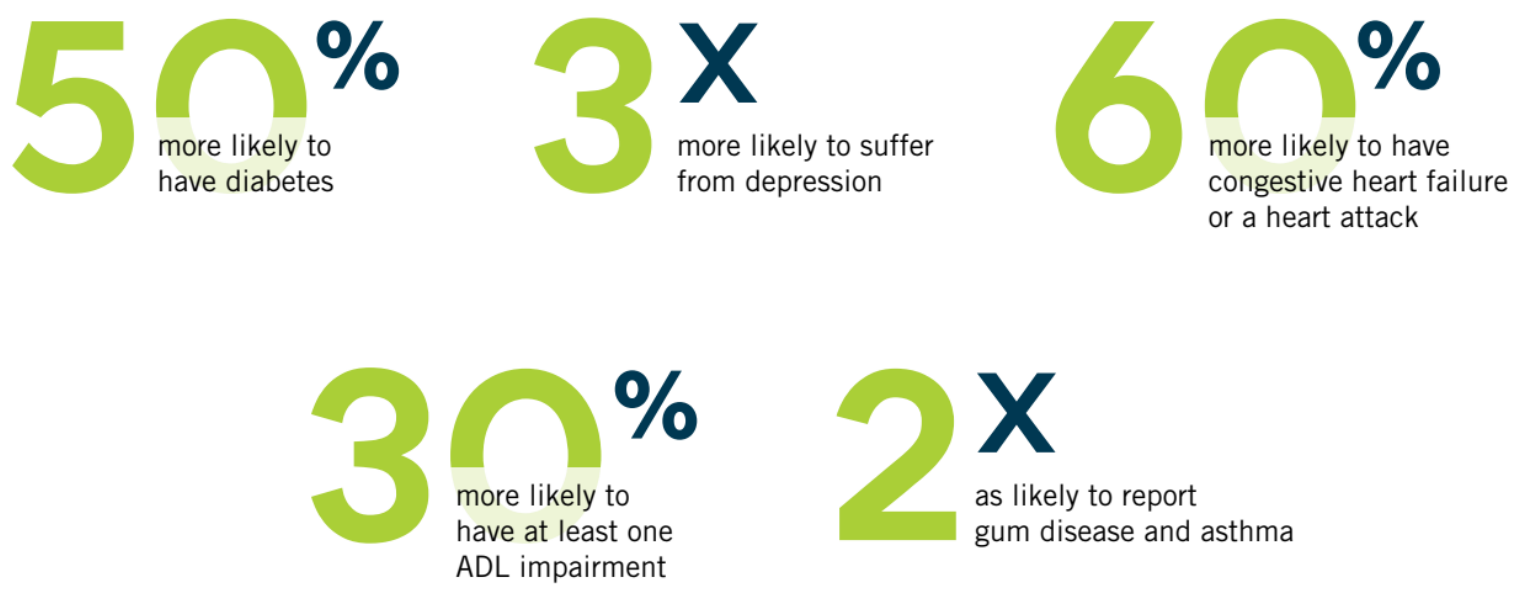

as likely to report

gum disease and asthma

These multiple chronic health conditions can reduce a person's ability to bathe or dress himself, or to shop and prepare meals. Health, functional and income limitations may lead to coping strategies such as eating less food or the wrong kinds of food, or making tradeoffs between buying food and medications or seeing the doctor. In turn, these poorer health outcomes may increase healthcare expenditures and the risk of nursing home placement.

Source: Meals on Wheels America: Hunger in Older Adults Report https://www.mealsonwheelsamerica.org/docs/default-source/research/hungerinolderadults-fullreport-feb2017.pdf 


\section{Exhibit 2: Food insecurity in America: trends and categories}

Trends in the prevalence of food insecurity and very low food insecurity in U.S. households, 2001 - 2018

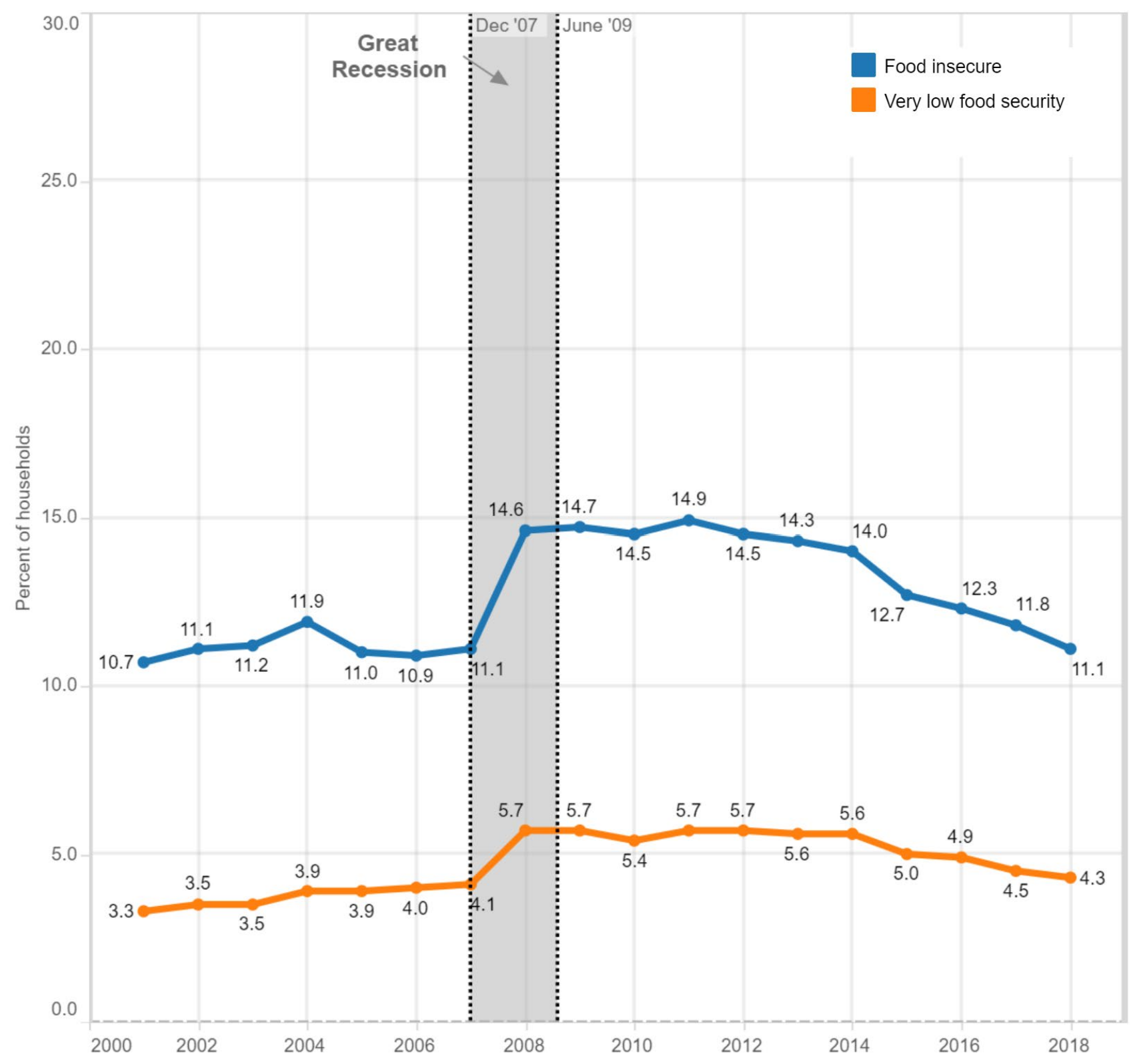




\section{Distribution of food insecure households}

\section{Education status}

What is the education status of food-insecure and very low food-secure households?

Food insecure

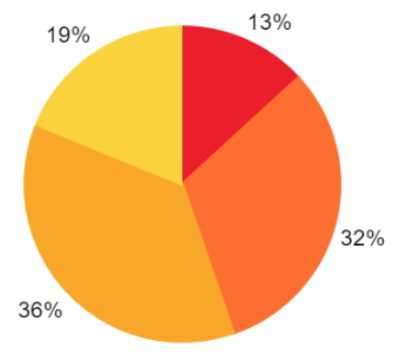

Very low food secure

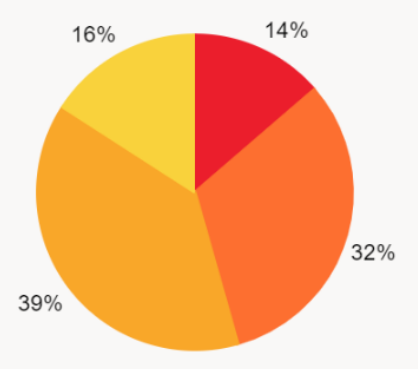

Education

Less than high school

High school

Some college

College or more

\section{Employment status}

What is the employment status of food-insecure and very low food-secure households?
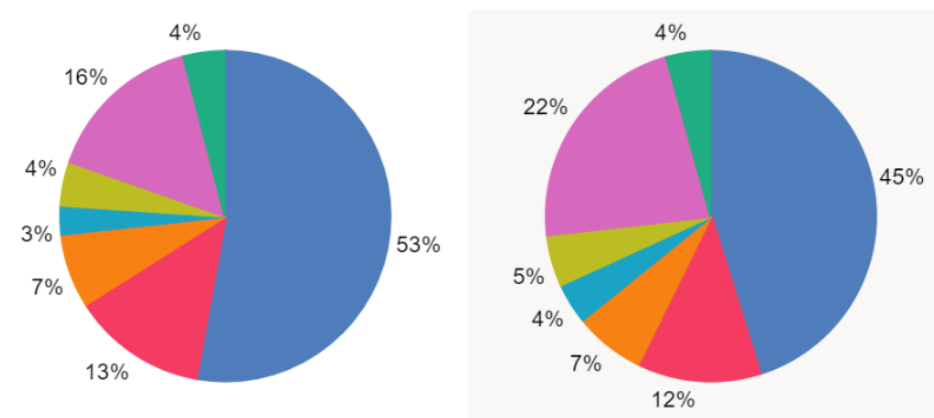

Employment

Full-time

Retired

Part-time for non-economic reasons

Part-time for economic reasons

Unemployed

Not in labor force - disabled

Other, not in labor force

Disability status

What is the disability status of food-insecure and very low food-secure households?
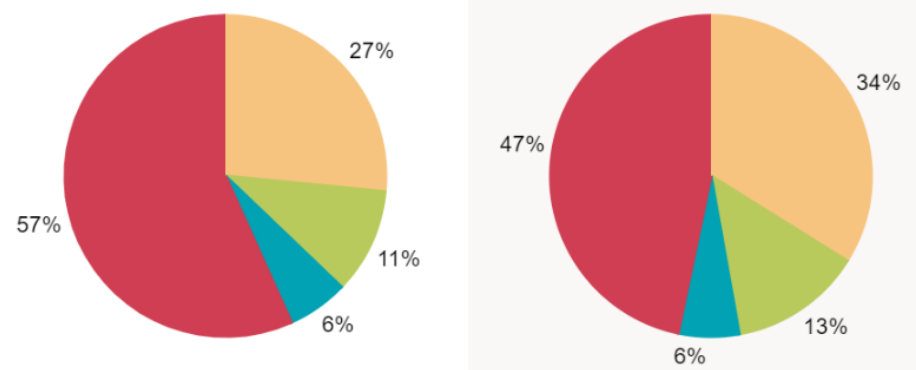

Disability status

Disabled, not in labor force

Disabled, adults 18-64

Disabled, adults 65+

Adults not disabled

Source: Calculated by USDA, Economic Research Service, using Current Population Survey Food Security Supplement data. https://www.ers.usda.gov/topics/food-nutrition-assistance/food-security-in-the-us/ 


\section{Exhibit 3: Forbes America's Top 10 Charities 2019 (private donations)}

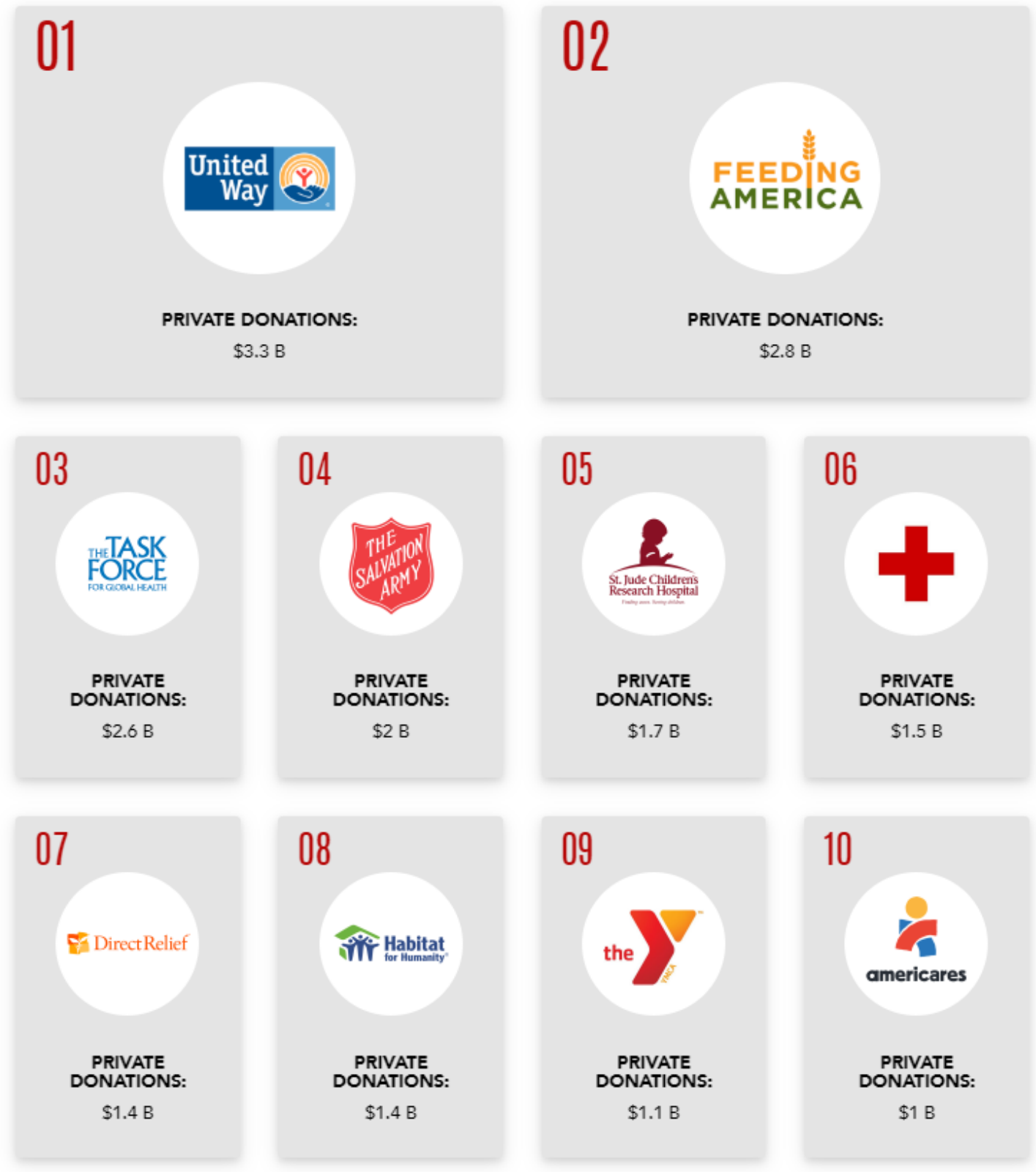

Source: Forbes web site: https://www.forbes.com/lists/top-charities/\#4e2019f55f50 


\section{Exhibit 4: Meals on Wheels of Tampa Timeline}

\begin{tabular}{|c|c|}
\hline Year & Milestone \\
\hline 1975 & $\begin{array}{l}\text { Meals on Wheels of Tampa (MOWT) was founded by Gloria Fuentes on March } 17^{\text {th }} \text {, by } \\
\text { making } 14 \text { meals in the recreation hall of the Northeast United Methodist Church }\end{array}$ \\
\hline 1993 & MOWT moved to current location on Hillsborough Ave. \\
\hline 1994 & $\begin{array}{l}\text { The State Attorney's Office and St. Mary's Episcopal Day School became first Adopt-A- } \\
\text { Route partners }\end{array}$ \\
\hline 2002 & MOWT hosted first "Nourish the homebound breakfast" fundraiser in March \\
\hline 2003 & Soup program for recipients begins weekly delivery, providing a supplemental fresh snack \\
\hline 2006 & Kitchen renovated to increase capacity \\
\hline 2007 & $\begin{array}{l}\text { Annual hurricane prep pack program began providing shelf stable meals and water in case } \\
\text { of emergency }\end{array}$ \\
\hline 2011 & $\begin{array}{l}\text { MOWT launched "Nonprofits helping Nonprofits", a social enterprise, where MOWT } \\
\text { produces and delivers meals to other area nonprofits, and uses the revenue to address the } \\
\text { funding gap created by recipients who are unable to afford the full cost of their meals }\end{array}$ \\
\hline 2011 & $\begin{array}{l}\text { A partnership is formed with The Humane Society, to provide pet food to recipient's furry } \\
\text { family members, once a month }\end{array}$ \\
\hline 2012 & Additional delivery routes created in Lutz area \\
\hline 2013 & Additional delivery routes created in New Tampa area \\
\hline 2014 & $\begin{array}{l}\text { MOWT partners with the University of South Florida College of Public Health to measure } \\
\text { the impact of its services on recipients. The results were later published in the Journal of } \\
\text { Nutrition in Gerontology and Geriatrics in } 2015\end{array}$ \\
\hline 2015 & Delivery service expands into the Palm River and Progress Village communities \\
\hline 2015 & March $17^{\text {th }}$ marks 40 years of serving the Tampa community \\
\hline 2015 & $\begin{array}{l}\text { Produce on Wheels (POW!) program begins monthly delivery to provide fruits and } \\
\text { vegetables as additional healthy snacks. Partnership is formed with Feeding Tampa Bay to } \\
\text { help pack and fill the bags }\end{array}$ \\
\hline 2015 & $\begin{array}{l}\text { Established High School Leadership Board (HSLB), a leadership program for high school } \\
\text { juniors and seniors to contribute to the program, act as MOWT ambassadors and become } \\
\text { leaders in the community }\end{array}$ \\
\hline
\end{tabular}




\begin{tabular}{|l|l|}
\hline $\mathbf{2 0 1 6}$ & $\begin{array}{l}\text { MOWT's High School Leadership Board (HSLB) developed and introduced a new } \\
\text { program, Water on Wheels (WOW!), to encourage healthy hydration }\end{array}$ \\
\hline $\mathbf{2 0 1 6}$ & $\begin{array}{l}\text { Launched a feasibility study to assess the possibility of building a new facility to meet the } \\
\text { growing demands of meal production and new programs }\end{array}$ \\
\hline $\mathbf{2 0 1 6}$ & $\begin{array}{l}\text { Implemented a new volunteer platform (Volunteer Hub) and increased volunteer } \\
\text { orientation schedule to twice a month }\end{array}$ \\
\hline $\mathbf{2 0 1 8}$ & $\begin{array}{l}\text { First MOWT 5K and Fun Run community event to raise awareness of senior hunger in } \\
\text { Tampa. Proceeds from this annual event go into the program }\end{array}$ \\
\hline $\mathbf{2 0 1 8}$ & $\begin{array}{l}\text { Added } 10 \text { new routes to meet the growing recipient numbers. Over } 800 \text { meals are delivered } \\
\text { every day, Monday }- \text { Friday }\end{array}$ \\
\hline $\mathbf{2 0 1 9}$ & $\begin{array}{l}\text { New website launched } \\
\text { Ground breaking ceremony for new facility September } 12^{\text {th }}\end{array}$ \\
\hline
\end{tabular}

Source: MOWT website https://MOWTampa.org 


\section{Exhibit 5: MOWT Board and Leadership Team}

\section{Board of Directors}

\begin{tabular}{|c|c|c|}
\hline Board Member & Title & Affiliation \\
\hline Jana Boehmer & President & James A. Haley Veterans Hospital \\
\hline Kathy Ritchie & Vice President & Rieth \& Ritchie, P.A \\
\hline Fred Wallrapp & Treasurer & Tribute Telecom \\
\hline Wilda Isabel & Assistant Treasurer & Fifth Third Bank \\
\hline Lucy Terrill & Secretary & Mosaic \\
\hline Mary Alvarez & Member-at-large & $\mathrm{N} / \mathrm{A}$ \\
\hline Michelle Backlund & Member-at-large & Pop Healthcare \\
\hline Ed Bass & Member-at-large & Xerox Business Solutions \\
\hline Doreen Greco Ide & Member-at-large & Coldwell Banker Residential Real Estate \\
\hline Dolores McIntosh & Member-at-large & $\mathrm{N} / \mathrm{A}$ \\
\hline Holly O’Brien & Member-at-large & William E Hahn, P.A. \\
\hline Ed O'Carroll & Past President & Mobilization Funding LLC \\
\hline Dennis Pitocco & Past President & BIZCATALYST $360^{\circ}$ \\
\hline Laura Sherman & Member-at-large & Baldwin Krystyn Sherman Partners \\
\hline Robert Shimberg & Member-at-large & Hill Ward Henderson \\
\hline Cathy Smith & Past President & PAR, Inc. \\
\hline Marshall Tucker & Member-at-large & TECO \\
\hline Doug Tuttle & Past President & N/A \\
\hline Beverly White & Member-at-large & Gibbons | Neuman \\
\hline
\end{tabular}




\section{Leadership Team}

\begin{tabular}{|l|l|}
\hline Staff Member & \multicolumn{2}{l|}{ Title } \\
\hline Steve King & Executive Director \\
\hline Lany Pineda & Execute Chef / Senior Food Services Officer \\
\hline Cindy Vann & Senior Finance Officer \\
\hline Kristin Maximo & Senior Development Officer \\
\hline Shana Taylor-Page & Senior Operations Officer \\
\hline Jan Costello & Director of Programs \& Partners \\
\hline Kelly Santos & Program Coordinator \\
\hline Yvette Rouse & Program Coordinator \\
\hline Source: MOWT & Volunteer Program Specialist \\
\hline
\end{tabular}

Source: MOWT website https:/MOWTampa.org 


\section{Exhibit 6: Donations by amount, fiscal year ending June 2019}

\begin{tabular}{|l|c|}
\hline Amount Donated (US\$) & Number of Donors $\left(^{*}\right)$ \\
\hline $\mathbf{1 0 , 0 0 0 +}$ & 42 \\
\hline $\mathbf{5 , 0 0 0}-\mathbf{9 , 9 9 9}$ & 30 \\
\hline $\mathbf{2 , 5 0 0}-\mathbf{4 , 9 9 9}$ & 37 \\
\hline $\mathbf{1 , 0 0 0}-\mathbf{2 , 4 9 9}$ & 210 \\
\hline $\mathbf{5 0 0}-\mathbf{9 9 9}$ & 160 \\
\hline Up to 499 & 2491 \\
\hline
\end{tabular}

(*) Excluding anonymous donations

Source: MOWT website https://MOWTampa.org 


\section{Exhibit 7: Birthday card sent to volunteers}
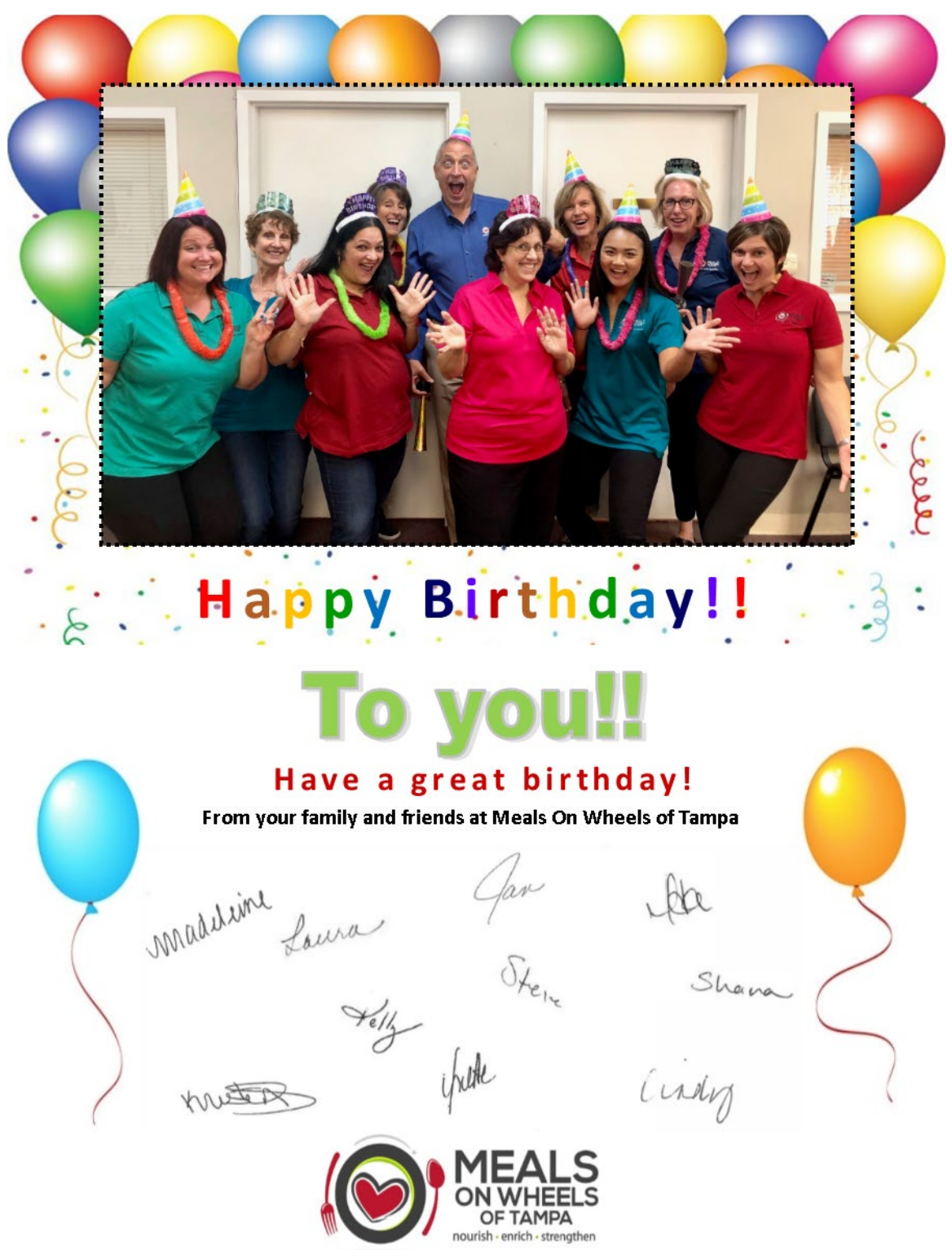

Source: MOWT email to author 


\section{Exhibit 8: Adopt-A-Route participating organizations (as of May 2020)}

\begin{tabular}{|c|c|c|}
\hline 13th Judicial Circuit Judges & Kimley Horn & St. Mary's Episcopal Day School \\
\hline Adcock Financial & MacDill AFB & Suncoast Credit Union \\
\hline Alorica & MacDonald Training Center, Inc. & Suncoast New Options \\
\hline Alpha Phi Omega USF & $\begin{array}{l}\text { Meals On Wheels of Tampa } \\
\text { Board of Directors }\end{array}$ & Sunrise Group \\
\hline $\begin{array}{l}\text { Baldwin Krystyn Sherman } \\
\text { Partners }\end{array}$ & Meals On Wheels of Tampa Staff & Synergy Florida \\
\hline Bank OZK - MacDill & Melba Lee Inc. & Syniverse Technologies \\
\hline Bay Hope Church & MHD Communications & Tampa Bay Lightning \\
\hline Brew Bus & Morgan Stanley & Tampa City Attorney's Office \\
\hline Brimmer, Burek \& Keelan & Mutual of America & Tampa Covenant Church \\
\hline $\begin{array}{l}\text { Bryan Glazer Family JCC Men's } \\
\text { Group }\end{array}$ & New York Life Insurance & Tampa Interbay Rotary Club \\
\hline C.H. Robinson & New York Yankees & Tampa Preparatory School \\
\hline Carrollwood Service League & Openwater Church & TCM Bank \\
\hline CBRE & PAR, Inc. & TECO Energy \\
\hline Chubb Insurance & PFG Private Wealth Management & Temple Terrace Garden Club \\
\hline Cushman \& Wakefield & Police Athletic League (PAL) & Temple Terrace Jr Women's Club \\
\hline Delta & Quest, Inc. & Temple Terrace Women's Club \\
\hline Digital Hands & Rakuten & The Bank of Tampa \\
\hline Family Freedom Insurance & Ready Realty & The Mosaic Company \\
\hline Florida Hospital & Reeves Subaru & The Northdale OWLS \\
\hline Greenacre Properties & RMC Property Group & Trinity School \\
\hline Grow Financial & Roche Surety and Casualty & United Healthcare \\
\hline Healthy Hotties & Rose Group Keller Williams & USAA New Tampa office \\
\hline $\begin{array}{l}\text { Hillsborough County Property } \\
\text { Appraiser's Office }\end{array}$ & Rotary Club of New Tampa & USF Health Service Corps \\
\hline $\begin{array}{l}\text { Hillsborough County Sheriff's } \\
\text { Office }\end{array}$ & Ryan Companies & USF School of Aging Studies \\
\hline $\begin{array}{l}\text { Hillsborough County State } \\
\text { Attorney's Office }\end{array}$ & $\begin{array}{l}\text { Rywant, Alvarez, Jones, Russo \& } \\
\text { Guyton, P.A. }\end{array}$ & Warren Averett \\
\hline $\begin{array}{l}\text { Hillsborough Women's } \\
\text { Republican Club }\end{array}$ & Seacoast Bank & Whitney Transport \\
\hline Jesuit High School & SME Solutions Group & Xerox Business Solutions \\
\hline Johnson \& Johnson & $\begin{array}{l}\text { Southwest Florida Water } \\
\text { Management District }\end{array}$ & Ybor City Rotary Club \\
\hline Kforce Staffing \& Solutions & St. Lawrence Catholic School & \\
\hline
\end{tabular}

